\title{
CLIMATE CHANGE AND ECONOMIC CRISIS: HOW TO REDUCE BOTH
}

\author{
Cristina García Fernández \\ Departamento de Economía Aplicada V \\ Universidad Complutense de Madrid
}

http://dx.doi.org/10.5209/rev_NOMA.2013.v40.n4.48342

\begin{abstract}
Summary.- Today we have several preventive economic policies that are designed to reduce emissions of greenhouse gases (GHG). The existing literature usually defines these policies as cost-efficient for they can achieve a significant reduction in emissions without having to incur in a very high cost. Likewise, these policies are also cost effective provided that they not only achieve significant cuts in emissions of the most released gas in the atmosphere, but also other greenhouse gases. For example, increasing energy efficiency not only reduces carbon dioxide emissions but also other gases that highly contribute to global warming. In addition, greater efficiency can make industries and countries become more competitive in international markets.

In the current context of economic crisis the level of efficiency becomes even more important. We need to be efficient to save on costs and to produce with more sustainably but this goal cannot be achieved without changing the current production model.

The carbon tax is an incentive that has a double advantage. First, it is an efficient option to palliate climate change as it is able to achieve emission reductions without incurring in excessive costs. Second, is in itself, an incentive to achieve a gradual change towards a more sustainable production system, which is no doubt a claim for the current crisis. The purpose of this paper is, therefore, to analyze the case of the carbon tax, for being the incentive that implements greater efficiency in the market and for constituting an effective option for palliation the current global crisis negative effects.
\end{abstract}

Keywords.- climate change, carbon tax, economic efficiency, economic crisis, costs of reducing carbon emissions and preventive economic policies.

\section{Introduction.}

The purpose of this paper is to study the carbon tax in a theoretical frame. We analyze the advantages and disadvantages of its use as an incentive that is able to reduce carbon emissions and achieve greater economic efficiency in the current crisis. We'll see how the carbon tax is an efficient option in preventing climate change as it can achieve emission reductions without incurring in excessive costs. No doubt this is a great advantage. In addition, a good management of this instrument can be an interesting option to deal with some of the economic problems we are going through today.

First we present some of the most important assumptions that explain the current global warming state. Secondly, we will see how this situation will lead us to rethink the current production model and the need to modify it. Finally, we 
analyze the ability of the carbon tax, as compared to other preventive policies, to gradually transform the current model to a much more sustainable one.

\section{Assumptions}

When we talk about global warming and, consequently, climate change, we must not forget two basic issues: first, that human activity is the cause of the changing climate and, second, that the climate change process is unstoppable because it is associated with the climate system's long time scales. We show both assumptions with two simple schemes:

Table1. Human activities cause climate change

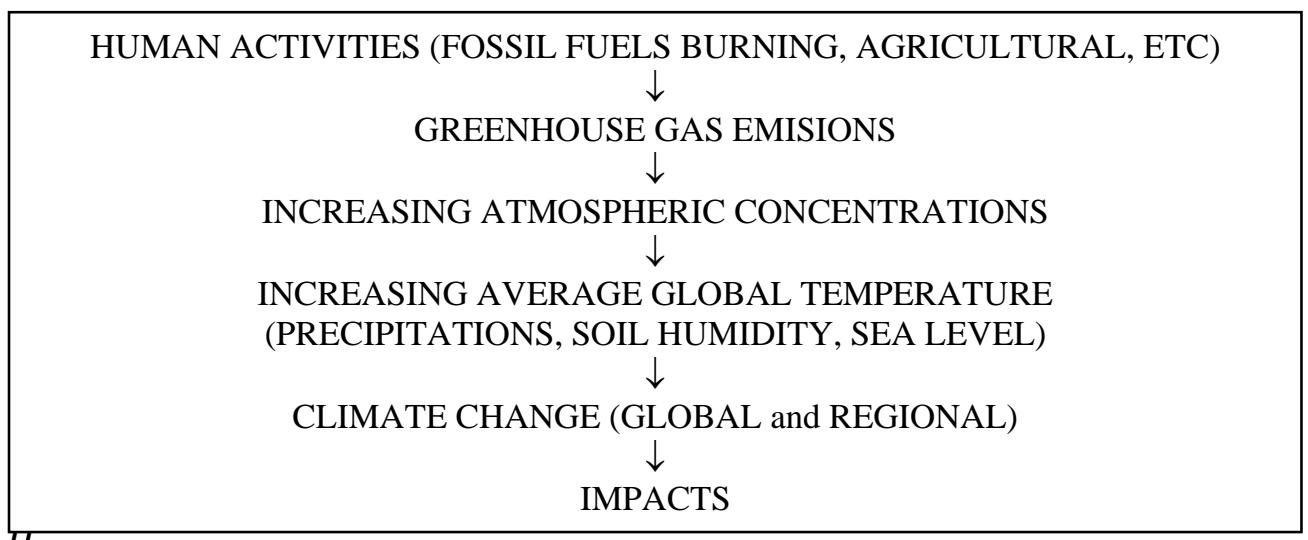

Table 1 summarizes the whole process of the climate change phenomenon. It all starts with human activities that expel gases into the atmosphere. These turn into concentrations that can hardly be eliminated and which raise average global temperature. Such increases in temperature alter the various parameters related to climate (rainfall, etc) which eventually lead to global and regional climate changes. Since the financial crisis began (late 2007), and throughout these six recent years, we have been hearing that during the crisis emissions have been reduced due to the slowdown in demand for electric power. Although we will address this issue later in this paper, it is worth noting that the problem lies in the atmospheric concentrations of GHG as these have not been reduced by the effects of the crisis. 
Table 2. The process is unstoppable due to Long Time Scales associated with the Climate System

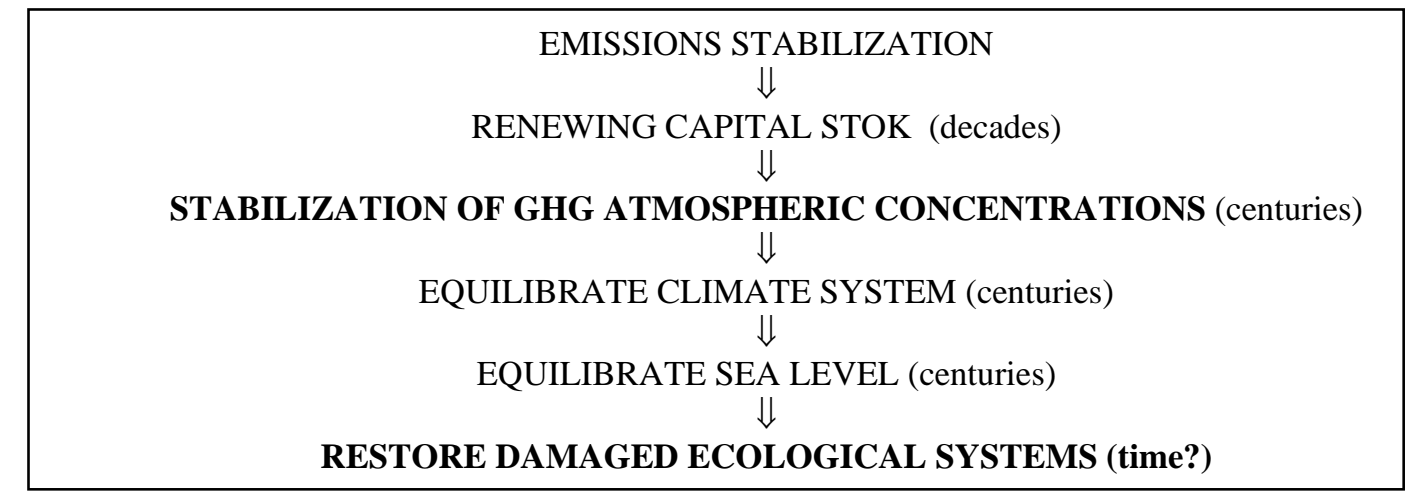

Source: Own

Table 2 shows a very simple example. If we started on a situation that all the emissions had already been stabilized (which is not the case), yet it would take decades for all the obsolete capital to be renewed, centuries for stabilizing concentrations and much longer to achieve the restoration of all damaged ecological systems.

Therefore, the current situation is very complicated and the case of "doing nothing" or "business as usual" is not acceptable, even more, when emissions in recent decades have increased at a rate of $80 \%$ (IPCC, 2007).

This trend is illustrated in the following table:

Table 3. Evolution of GHG emissions 1970-2004

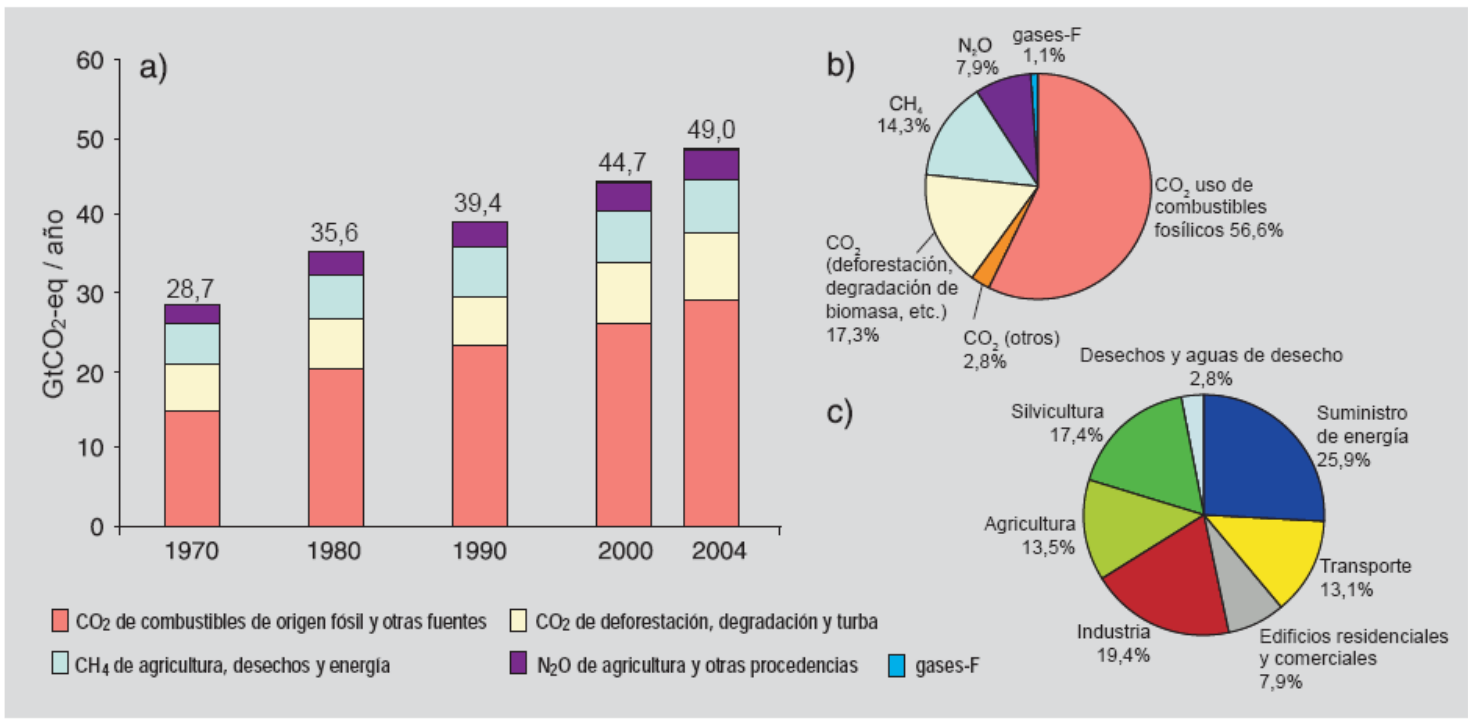

Source: IPCC, 2007. 
Table 3 shows GHG emissions (in C02 equivalent) for several years. It also indicates the origin of emissions by economic sector. Clearly, it's the $\mathrm{C} 02$ from the use of fossil fuels the most emitted and growing in time greenhouse gas.

Due to this fact, the past climate summits (Cancun 2010, Durban 2011 and Doha 2012) have imposed ambitious temperature targets setting a ceiling of 2 ० $\mathrm{C}$ above pre-industrial levels. To achieve it, developed countries as a group should reduce their emissions between 25 and 40\% (relative to 1990) in 2020 and between 80 and $95 \%$ in 2050. This is a very ambitious target for all countries of the world, since achieving these temperatures means radical changes in economic and energy structures. If no action is taken in this sense, the average global temperature could rise up to $6.4^{\circ} \mathrm{C}$ by the end of the century (IPCC, 2007).

We have already said it. The current production model, still largely based on fossil fuel consumption and the depletion of natural resources does not work if our aim is to get a more sustainable society.

\section{A change in the production model.}

Today fossil fuel prices are starting to rise (excluding coal) after the fall they experienced at the beginning of the crisis (2008). The drop in price during the first two years of the crisis seemed an incentive for lower extraction and consumption thereof.

Although the recession brought a general decline in energy (especially electricity) due to the fall in GDP (see Figure 1), this trend has been smoothing. In general, the forecasts suggest that coal and natural gas will continue to dominate electricity generation (the sector producing largest $\mathrm{CO} 2$ emissions), although their combined shares will be reduced significantly in OECD countries due to the expansion of the renewable and nuclear energy. However, in Asia and North America it seems that the demand for fossil fuels, particularly coal, will continue to increase. It will also increase in most of the emerging countries. This is because it is where we still find the greatest reserves of this fuel. 
Figure 1. GDP and electricity demand.

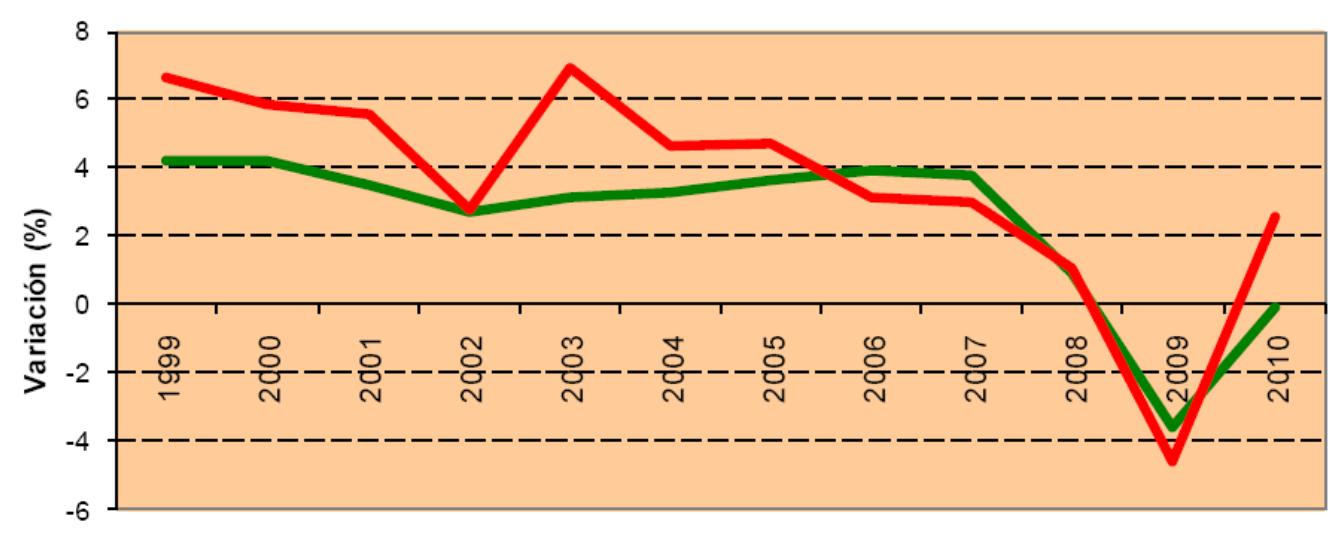

Variación PIB (\%) Variación Demanda Eléctrica (\%)

Source: National Energy Commission (2011).

Figure 1 shows the correlation between GDP and electricity demand in Spain. The economic crisis resulted in a decline of the economic activity which produced significant cuts in consumption and production of energy. This trend appears to have changed today, where energy consumption patterns have been reversed, although not completely, the trend shown in the first years of the crisis. Something similar has experienced the price of fossil fuels since after having sharply fell in the first years of crisis they have modified this trend. Forecasts indicate an upward trend with the exception of coal (Figure 2).

\section{Figure 2. Historical evolution of fossil fuels price and future prospects.}

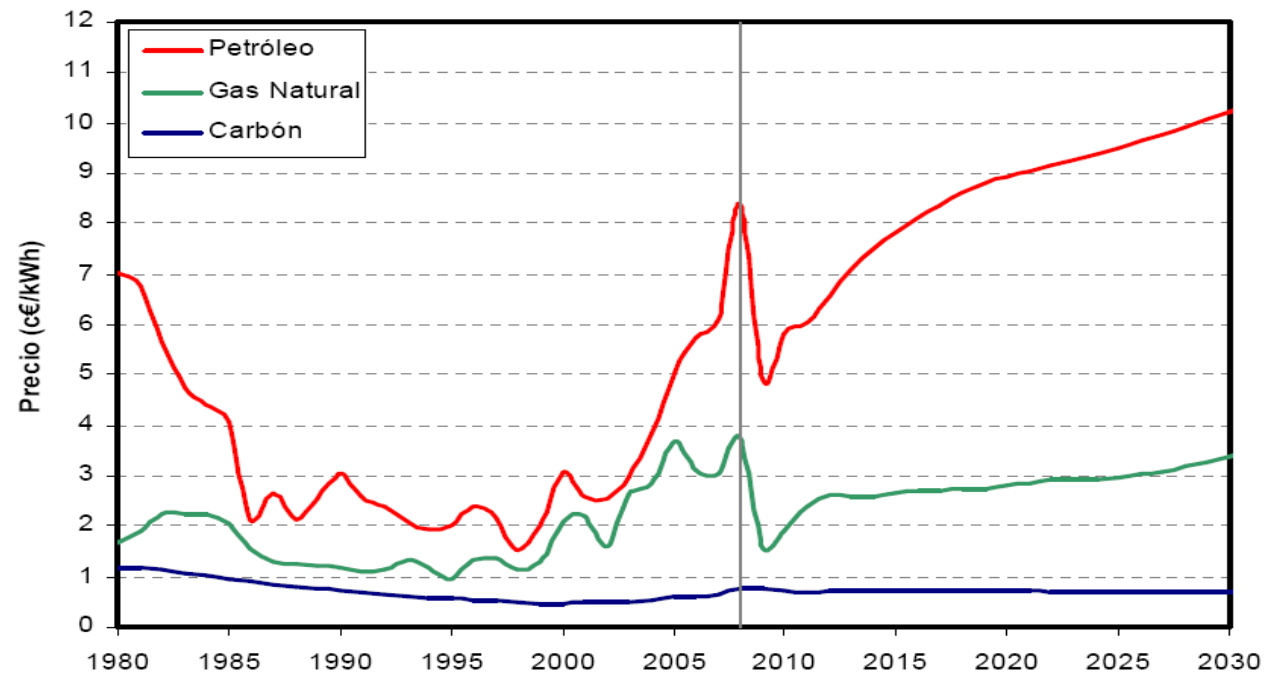

Source: International Energy Outlook 2011. U.S. Department of Energy (DOE), 2011. 
As shown in Figure 2 and, unlike oil and natural gas, the price of coal will remain stable or even decrease slightly in the following decades. This resource is still very abundant and it is estimated that there are reserves for the next 200 years. It is expected that the electricity price from this energy source will increase over time. The oil and natural gas prices show an upward trend which encourages their use in the future.

Figure 3. World Energy Consumption, 2007-2035
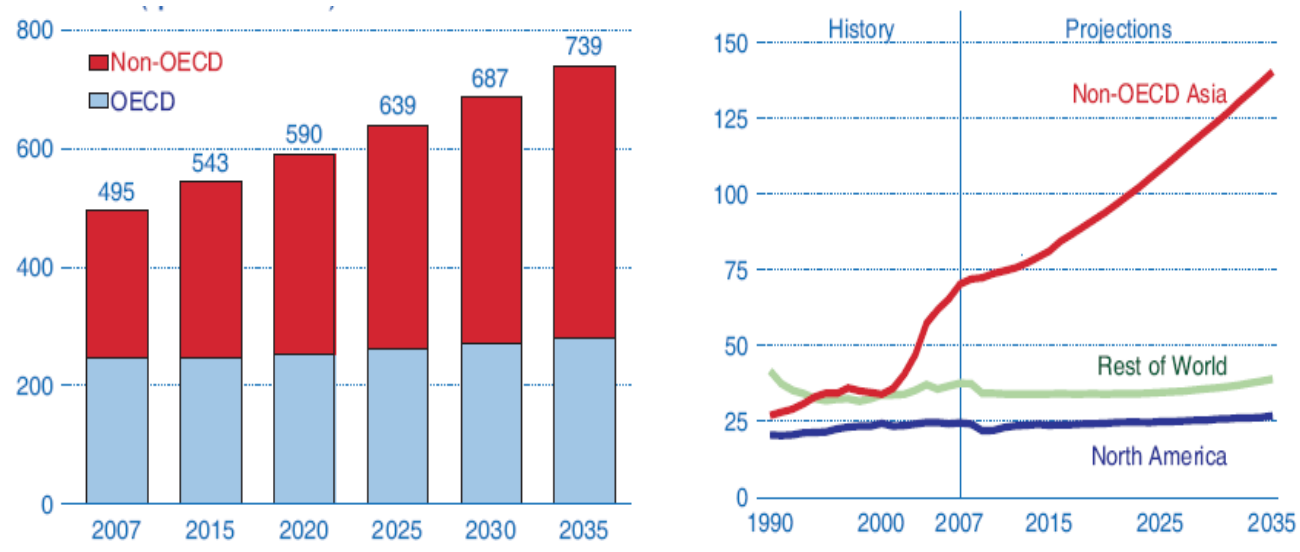

Source: International Energy Outlook 2011.

Figure 4. World energy consumption by fuel type and world coal consumption by region.
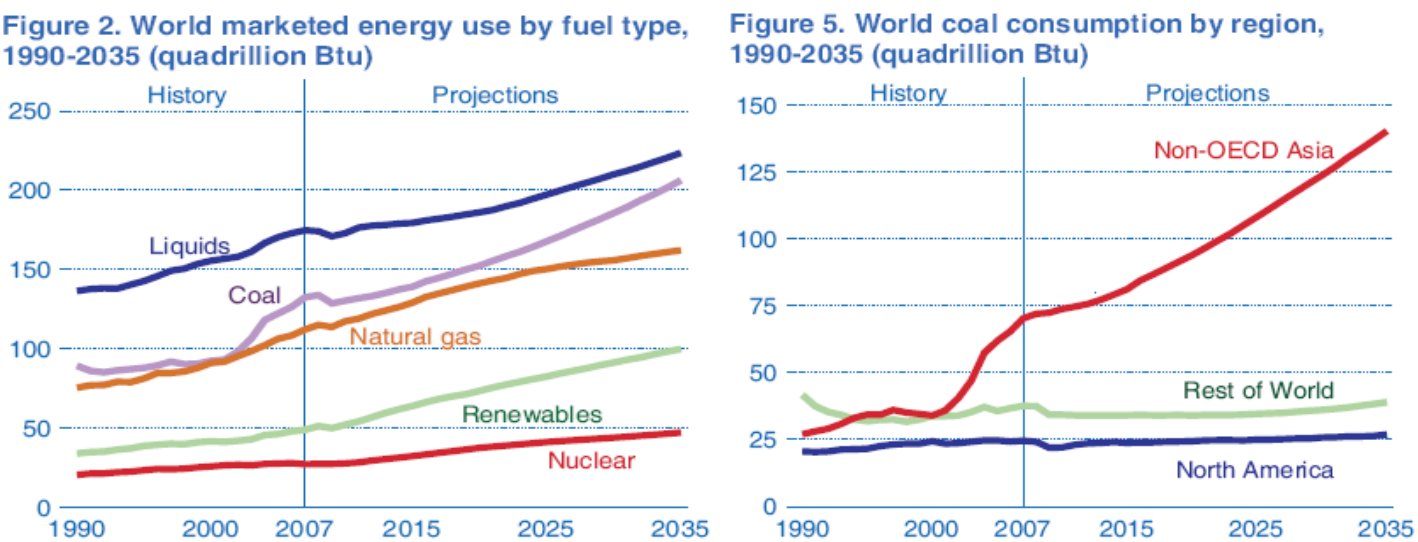

Source: International Energy Outlook 2011. 
As shown in Figure 3, the rate of energy consumption for the coming years, especially in countries outside the OECD, will not be sustainable if the expected trend materializes. Fossil fuels like oil and natural gas have a production ceiling and proven estimated reserves of about 50-60 years and about 190 years for coal. This situation, combined with the upward price trend, leads us to an uncertain future in terms of environmental sustainability.

Without a radical change in the energy model (Figure 4), the forecast for 2030 points to a world energy consumption of $60 \%$ higher than today, with oil and coal being the higher consumed sources, natural gas having the higher growth rate, and a slight increase for nuclear and renewables (International Energy Outlook, 2011). In the first decade of the century, the U.S. consumed $25 \%$ of global energy with just over $4 \%$ of the world population. If this trend continues, by 2030 the countries with higher energy consumption will be China (which will triple the current one), USA (increase of 70\%) and India (nearly quadrupled). Overall, according to the IEO (2011), global energy consumption between 2005 and 2030 may represent an increase of $60 \%$.

The sustained performance of coal at a very low price (Figure 2) together with the expected increase of global energy consumption (figure 3) and the rate of growth of fossil fuels (Figure 4) do suggest that carbon emissions will continue to rise. While it is true that during the crisis these have descended, emissions data tell that they may continue to increase in the future. Therefore, in order to prevent this from happening, together with the emergency of promoting energy efficient technologies, it becomes necessary to implement mitigation market policies in all countries.

It is important therefore to introduce an incentive that changes this situation. It is necessary then that the price of coal evolves at least in a similar way as it is expected for oil and natural gas. The introduction of a carbon tax increases the price of the fossil fuels driving down consumption, and encouraging the replacement of these by other cleaner energy sources. It also sets up the mechanism of cross-elasticities (see "the elasticity issue"). Annex 1 shows a study of how a tax of $\$ 27$ per ton of carbon increases the price of coal and oil causing a fall in consumption of these fuels and increasing natural gas demand (cross-elasticity of coal and natural gas and oil and natural gas).

\section{The best instrument in the context of economic crisis}

Summarizing the discussion in the previous sections we can conclude that the current situation is: 1) the crisis has reduced emissions but not concentrations, 2) the current uptrend in the price of fossil fuels is an incentive to continue extracting, 3) there are still large coal stocks in emerging countries, 4) forecasts suggest that coal and natural gas will continue to lead power generation, 5) demand for coal (the most CO2 emitting fuel) will continue to rise in Asia, North America and many emerging countries and 6) only OECD countries will reduce consumption of fossil fuels due to the expansion of renewable and nuclear energy. This situation urgently demands the implementation of preventive economic policies in order to reduce the use of fossil fuels and promote its 
gradual replacement by other energy sources. To do this, we must avoid incurring in excessive costs. This is where we approach the economic policy and the efficiency frames.

The use of economic instruments in environmental policy enables compliance of environmental objectives at a minimum cost (static efficiency), while introducing incentives for continuous environmental improvement (dynamic efficiency) 1. Given that this is true for any environmental problem in which there is a large number of pollutants of various kinds and origin, in the case of climate change is even more important. This is because, first, there are many heterogeneous polluters (virtually all economic agents pollute), from different economic sectors that generate emissions, many related to technological obsolescence. Second, because the cost associated with reducing emissions is potentially so high that it is essential to try to achieve the efficiency gains.

The cost problem has been one of the crucial issues in using economic instruments in the field of climate change. It is reasonable that economists try to find efficient alternatives that do not only control the emissions, but that also do not become too expensive. That is why the primary objective of any palliative policy (specifically atmospheric) is to be cost-efficient so that we can obtain the maximum emissions reduction for a given level of expense.

In general, economists tend to say that a combination of policies is usually the best option, since the use of any instrument will depend on various factors at all times. Nevertheless, after comparing in different studies2 different economic instruments, like pure regulatory systems, carbon markets and carbon taxes, we can conclude that the carbon tax has a threefold advantage over the use of other incentives:

1. Generally, a tax on emissions provides stronger incentives to develop and implement new and cleaner technologies than any other policy based on the quantitative control of emissions. This means that the tax dynamic efficiency is higher.

2. Carbon tax is able to get a net carbon emissions cut, as companies, in order to reduce the amount of the tax will have an additional incentive to reduce their emissions.

3. The tax is a better option than the emissions permit system since the later provides a result that depends on the initial allocation of permits (which has implications for their distribution) and on price changes ( permits set a price per unit or per ton of carbon), (Paltsev, al, 2005). This is relevant because the carbon price fluctuation makes it difficult to estimate the total cost that the issuing permits would involve. In general, emission permits generate greater

\footnotetext{
${ }^{1}$ Static efficiency. This criterion refers to the cost of achieving a given environmental improvement through the application of an specific instrument. The lower the cost, the more attractive the instrument will be. Dynamic efficiency. The ability of an instrument to create incentives that lead to the development of new and better technical solutions that solve environmental problems.

2 For a comparative analysis of the instruments see (García, C; 2008, 2009, 2010 y 2013).
} 
incentives for technological development than pure regulatory systems but, in many cases, they constitute a weaker incentive than the carbon tax. The explanation is simple. If several companies adopt new technologies, the total demand for permits, together with their price, will fall. Then the profitability of adopting the new technology will decrease and with it the incentive to develop new methods of production. Furthermore, emission permit markets are highly speculative as their operations revolve around the prices behavior. All this makes the tax a better option.

Market instruments have always been a tool used by environmental economists since they have a very direct application for most environmental problems. Climate change is an environmental externality that requires urgent action by all the countries. Today, in the context of economic crisis market incentives become a necessary claim since they clearly constitute public intervention mechanisms. This means that taxes can get very interesting advantages from the cost efficiency point of view (static and dynamic efficiency). We already know that the carbon tax encourages dynamic efficiency, ie, the development of more efficient technologies. Moreover, in the crisis context taxes are becoming more necessary to counteract the potential increase in fossil fuels demand, particularly the coal, for its moderate prices and large stockpiles, the oil, for its abundant reserves, and, the natural gas, being now an alternative energy source to the most polluting fossil fuels. Finally, as noted Labanderia (2011)3, if we can increase the prices of energy products through market instruments this will lead to improvements in energy efficiency, reducing external vulnerability and dependence.

\section{The carbon tax. Reflections.}

In this section we consider three issues regarding the design of the tax: the base, the tax rate and the distributional aspects. We will also make a brief reference to trade. The purpose is to define how a tax would fulfill the optimality conditions (see Pigou, 1938), or at least internalize the externalities produced by emissions without incurring in excessive administrative costs. We don't take into account political issues such as the concessions that would be necessary for the establishment of any consensus imposed by under any international agreement.

\section{Definition:}

The clearest definition of a carbon tax is that of James Poterba's (1991): "A specific tax, that is a fixed absolute amount per ton of coal or a barrel of oil. The tax is designed to internalize the externalities associated with fuel consumption, so that should not vary to 0 shocks in fuel prices as it would an ad valorem tax. "The World Resources Institute (WRI), defines the carbon tax as "a tax on producers of fossil fuels, based on the carbon content of fuels."

\footnotetext{
${ }^{3}$ GAGO, A; LABANDEIRA, X. "Cambio climático. Impuestos y Reformas Fiscales". Estudios de Economía Política, 19 (2011):147-161.
} 
The carbon taxes are proportional to $\mathrm{CO}_{2}$ emissions when the fuel is burned. A carbon tax creates an incentive for producers and consumers: avoiding paying the tax by reducing the use of carbon-intensive fuels. Unlike other products and taxable activities, tax evasion generates important social benefits such as reducing energy use and cuts in $\mathrm{CO}_{2}$ emissions. Such reasoning has led to a variety of proposals based on the idea of "carbon tax". The general idea is that the fuel should be levied on the amount of carbon contained. The amount of carbon in the fuel, together with the amount of this being used, determines how much carbon dioxide is emitted into the atmosphere. The carbon-containing fuels differ in the quantity of this: coal is the fuel that contains more carbon, followed by oil and natural gas. According to this, coal should be taxed more strongly than oil and this one than natural gas. The non-carbon fuels, such as nuclear power and renewable energy sources would escape the tax and therefore should be more economically attractive options.

\section{Environmental Fiscal Reform}

A well designed carbon tax can create significant environmental and economic benefits. A strategy to establish a domestic effective tax on carbon that captures the benefits described above must meet three general requirements (WRI, 1995)4:

1 - Minimize economic losses, that arise in the short term, through the efficient use of the tax revenues.

2 - Maximize economic returns by reducing other taxes.

3 - Compensate negatively affected groups.

This is what we know today as the Environmental Tax Reform. This reform uses taxation and other fiscal instruments to capture revenues while benefiting the environment. For developed countries, carbon taxes can replace other taxes, such as taxes on income and capital as well as improving economic conditions reducing unemployment. In developing countries, revenues from carbon taxes can be allocated on poverty measures such as infrastructure development or creating incentives for a more energy efficient industry. The environmental tax reform provides an opportunity to develop tax strategies that mitigate climate change while improving economic growth and development.

Nowadays, it is necessary a tax reform which uses the public revenue from carbon taxes to reduce other taxes that distort and discourage labor or capital. This reform is especially needed to boost economic activity and growth, even more when we move in a context of very inflated public deficits. It becomes more interesting when there is no loss of resources to the public sector. In times of economic crisis, more than ever, we need to see implemented the so called multiple dividend taxation of GHG, that is, environmental improvement,

\footnotetext{
${ }^{4}$ World Resources Institute. (1995).
} 
promotion of clean technologies, reduction of energy dependence and increase of employment and economic activity5.

\section{Costs and benefits}

Compared to a system of emission permits, the carbon tax is less complex for governments and provides greater certainty regarding the cost for the polluters. Governments will tax polluters for every ton of $\mathrm{CO} 2$ emitted into the atmosphere. Thus, the polluter has a incentive to reduce $\mathrm{CO} 2$ emissions, which is just avoiding the tax and therefore approximate their benefits to costs with greater certainty. The tax is less complex for governments because many countries impose a tax on vehicles based on emissions levels, which makes the carbon tax a complement to other previously existing taxes (although determining the carbon content is not so simple at times). This, together with the carbon tax revenues, constitutes an important advantage. The disadvantages are the unpopularity among the political classes and the most affected sectors (industry, energy, residential, etc).

Meanwhile, in association with the tax there is a reduced level of contamination and related to this there is a cost, the cost of achieving a marginal reduction. Not knowing the appropriate tax is the same as not knowing the appropriate pollution abatement. Up to date, there have been several proposals to implement different emission levels.

One reason to prefer the carbon tax is that reducing emissions depends not only on the magnitude of the tax, but also on the price of fossil fuels, and this price is variable. For example, if the price of oil remains high, it is possible for many countries to achieve the emission reduction goals without incurring in additional costs, ie, without spending money on avoiding potential climate change damage (there are studies that show the correlation between the rise in the oil price and the emission reductions) 6. On the other hand, if oil prices decrease to its previous levels, the cost of carrying out a quantitative target may become very high. If we impose a tax, we can be sure we will always have an incentive to reduce emissions. This is one of the great virtues of a carbon tax.

Therefore, we can say that the total cost of reducing emissions may be lower if we implement a carbon tax policy, since, as each producer using fossil fuels pay the same tax, each of them will therefore have the same incentive to reduce emissions (Figure 5). However, the same cannot be applied to other policies. For example, by imposing a tax on oil (a single type of fossil fuel), vehicle owners have a greater incentive to reduce emissions than other pollutants, so that the cost of dealing with emissions reduction would be excessive. Then, with the carbon tax we could always redistribute to poorer groups the efficiency advantages of the tax, that is, the difference between the costs of achieving a certain level of emissions reduction with the carbon tax and the potential costs of an alternative policy.

\footnotetext{
${ }^{5}$ The unemployment issue varies depending on the studies.

${ }^{6}$ Metcalf y Weisbach, 2009
} 
Figure 5: The costs of reducing emissions with a tax

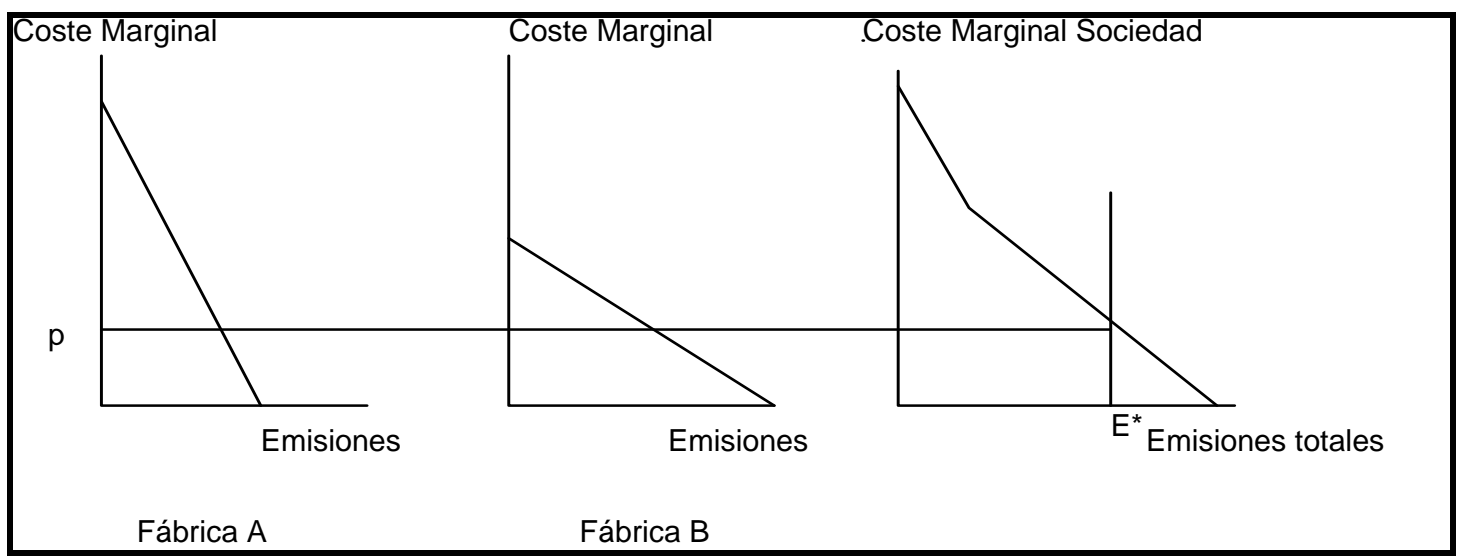

Source: own.

Figure 5 shows the costs of reducing carbon emissions in the two factories. The emissions are measured along the excises axis. The marginal cost curves show the cost of reducing emissions in one unit. The curves are decreasing indicating that large emission reductions increase the cost of reducing an additional ton of pollutant. We can impose a carbon tax rate of $p$ monetary units (euros, dollars, etc..) per ton of carbon. Fixed an overall goal in $E$ *, each factory will reduce emissions until the marginal cost equals the tax. Each unit will reduce pollutant emissions considering its $\mathrm{MC}$ (marginal cost) but will pay the same rate per ton of carbon. This would therefore be an effective policy.

\section{The tax base}

To answer this question we must first consider the problem of deciding by how much should the tax vary according to the fuel. As already mentioned, for the tax to be efficient it must be established on the fossil fuel carbon content7 (or CO2 emissions), and not on the use of fossil fuels. We also know that emissions vary with the type of fuel. The non-fossil energy sources such as hydro and nuclear, among others, do not emit $\mathrm{CO}_{2}$. Therefore, they will not be subject to this tax. However, these energy sources have their own environmental costs, so as a general rule economically efficient, prices should reflect environmental and social costs.

A more difficult question concerns the absolute magnitude of the tax. What size should this tax be?, the answer depends on whether the tax is the goal to be achieved or not. If the tax is the policy target, then we should ask: how much should emissions be reduced? The answer is not easy. One option would be to establish a carbon tax and observe the resulting emission reductions, rather

7 Since the atomic weights of carbon and oxygen are 12 y 16 respectively, one ton of carbon is equivalent to 3,67 tons of carbon dioxide. 
than setting a specific goal for emissions and try to calculate the tax that would be necessary to achieve it, although it is the most commonly used method.

Returning to the question about the tax size we must do some additional clarifications. If the tax is focused only on environmental considerations, the ideal tax rate should be one under which the benefits of reducing the last ton of carbon (marginal benefits) equaled the additional cost resulting from the elimination of that ton (marginal cost). As noted above, the theory does not often correspond with the practice since the equilibrium is not easy to achieve, especially in the case of benefits that can manifest over many future generations or situations in which science, or relative risks, are not sufficiently understood.

In fact, from the technical point of view, the tax or efficient policy could not be calculated until emissions really be translated into atmospheric concentrations, as are the concentrations, and not the emission levels, the ones which determine the global warming. Nor could be calculated until the effects of increasing concentrations were estimated, until the environmental and economic damage associated with temperature increases would be estimated and until the damage would be evaluated.

However, the general absence of formal data on environmental impacts does not prevent experts from developing programs focused on reducing the risks. Environmental taxes, which are widely being applied in many countries, are a very important preventive policy since they are a way to increase the price of certain goods, showing the social costs associated with their consumption.

Anyway, the most common method to determine the size of the carbon tax is to estimate the level of taxation which is necessary to achieve a given emission reduction. It is difficult to establish the "right" tax in advance for it also depends on the selected time period and the degree of control required. For example, the required tax that would stabilize emissions at 2015 level may be different from the tax that would stabilize emissions at a later date (2025). Most economic analysis on carbon emission reductions suggest that early emission cuts (the first 15 or 20 years) can be achieved with virtually no cost (reduced taxes). But as time goes by, maintaining or even increasing these reductions may be increasingly complicated, so we would need a higher tax. Nevertheless, efficient alternatives to fossil fuels, such as renewable energy and clean technologies are emerging, a fact that will involve a less severe taxation in the future.

On the other hand, when we talk of the tax base, we are trying to determine what should be taxed. In this process we must consider the marginal costs of reducing emissions (how much would emissions be reduced if an additional euro should be spent on this task). The reasoning is that to minimize the total cost of reducing emissions the tax base should include activities that have a low marginal cost of abatement but its total contribution to the generation of emissions is small. For example, if it is relatively easy to reduce methane emissions from landfills then, it may be important to include them in the tax base, although its contribution to emissions is not too high. The same would be attributable to other activities not related to fossil fuels (Reilly, et al , 2003). 
Therefore, when establishing the optimal tax base and taking into account the existing theory about it, we have to compare the administrative cost savings of having a small base with the efficiency gains we would get with a wider base. The base would be established so that the benefit of a slight broadening of the base equaled the increase in administrative costs of enlargement8. And so far the theory. The analysis of the real situation leads us to take into account other considerations, such as the complexity of political interests that would widen tax base. Many would oppose it. However, the advantage is that a broader base would lead to a lower tax rate in the long run, relaxing the opposition to the tax.

In general, the few existing carbon taxes have a rather narrow basis (five Scandinavian countries and the UK). Although the first taxes date from 1991 (Norway) they lack of a uniform rate for the emission sources they tax. Besides not being harmonized, these taxes are not very effective because of the multiple exemptions they have. The United Kingdom imposed a tax on climate in 2001. The rate influences the use of energy from industrial and commercial sectors, with domestic consumption and transport being exempt. Also, the tax rate is low9.

The European Emission Permits Market has a narrow base and covers a relatively small share of greenhouse gas emissions. According to Convery et al (2007), the European Commission estimated in 2010 that less than half of CO2 emissions and less than one third of the emissions of other GHGs were covered by the european emission permits system. For example, the transportation sector is excluded, although the excuse to do it were the existing taxes levied on gasoline and other fuels for automotive use.

\footnotetext{
${ }^{8}$ See Metcalf et al (2009). They provide a rigorous theoretical analysis regarding the costs and benefits to broaden the base of the carbon tax.

${ }^{9}$ Annex 2 shows the existing carbon taxes.
} 


\section{The tax rate}

A theoretical analysis based on the optimality of the tax is as follows:

\section{Figure 6: The optimal tax rate}

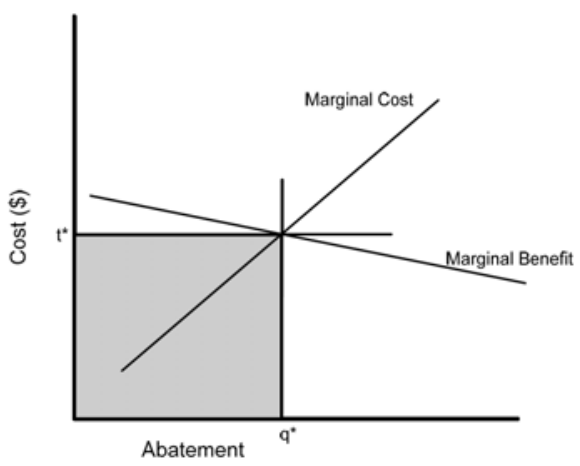

Source: Metcalf y Weisbach (2009).

To establish a tax as shown in figure 6 the government would need to estimate the marginal costs and benefits of reducing emissions. This is not an easy task as the government or the competent authority requires information about marginal cost and marginal damage. Previous work (Garcia, C, 2012 and 2013) show examples of how to estimate cost and marginal damage curves and the difficulty that this work entails since in order to do that we must have information (on costs and damages). Annex 3 of this paper shows a parallel analysis of the tax rate and costs.

Although, theoretically, the establishment of a carbon tax must meet economic efficiency conditions, in practice is not so simple, especially the calculation of impacts and their transfer to marginal damage. Due to the above, many analysts (Nordhaus, 2007) estimate a set of taxes, set at different points in time, linked to an emissions reduction target or levied to stabilize the total atmospheric carbon concentrations10.

\footnotetext{
${ }^{10}$ The IPCC Working Group II in reviewing 100 separate studies on the optimal tax, with a range from 3-95 dollars, estimates an average of \$12 per metric ton of CO2 by 2005. (Intergovernmental Panel on Climate Change (2007), p 16.).
} 


\section{Figure 7: Possible paths for emissions reductions from a cost perspective}

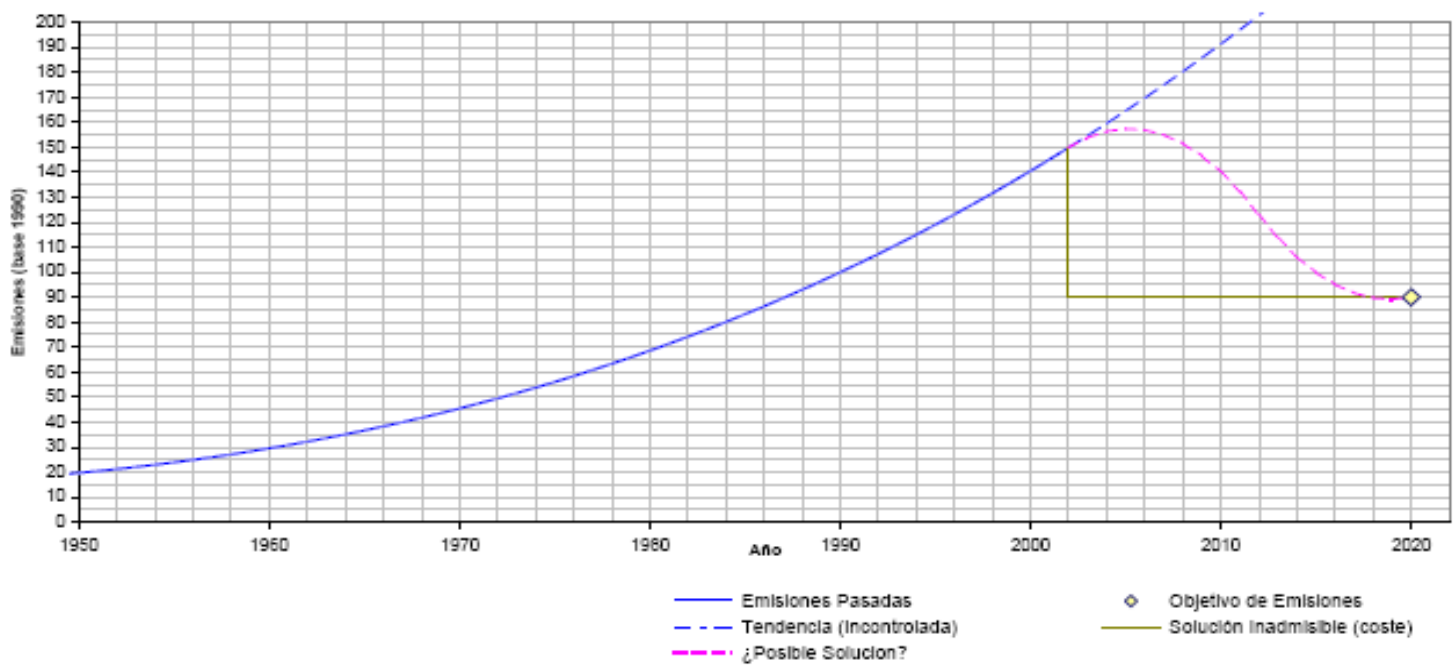

Source: own

Figure 7 shows a simulation of the possible paths we can take to reduce emissions and the costs they would bring in different cases. The key issue is to apply instruments that can achieve a gradual reduction in emissions since, otherwise, we may incur in excessive costs, missing the target of efficiency to which we have referred. In the graph, the optimal path would be the so called "possible solution" since it would get gradual emission cuts (in 2020) at a minimum cost or "cost-effectiveness". A gradual tax could implement that trajectory without incurring in too high costs (see section "progressive tax").

Several recent studies show conclusive results on the effect that different tax rates may have on the fuel price and the resulting emission reductions11. Some of the conclutions are showed below. Specifically, Dingell, Larson and Stara in Metcalf, GE et al (2008) show different tax rates that result in different emission paths. Clearly, more ambitious rates (Larson) get, eventually, greater emission reductions. However, for the first 15 years, the application of different tax rates does not achieve significant reductions. The study also considers the impact that these have on welfare, with the largest losses related to higher rates (Larson). These studies also show the revenue from the application of various carbon taxes. Their estimations of tax revenues for 2015 of relatively low taxes range between 69 billion dollars and 126 billion. This means that a tax of $\$ 25$ per metric ton of $\mathrm{CO} 2$ would increase the price of gasoline by about 22 cents per gallon and the price of coal 2.5 cents per KWh. The carbon tax also increases the price of other activities that use energy as an intermediate input.

\footnotetext{
${ }^{11}$ METCALF, G. E., S. PALSTEV, J. REILLY, H. D. JACOBY, and J. HOLAK (2008): "Analysis of U.S. Greenhouse Gas Tax Proposals," Cambridge: MIT.
} 
Table 4. Different carbon tax rates under study:

\begin{tabular}{|c|c|c|c|}
\hline & \multicolumn{3}{|c|}{$\mathrm{CO}_{2}-\mathrm{e}$ Price $\left(\$ / \mathrm{tCO}_{2}-\mathrm{e}\right)$} \\
\hline & Dingell & Stark & Larson \\
\hline 2015 & 14 & 10 & 20 \\
\hline 2020 & 14 & 23 & 32 \\
\hline 2025 & 14 & 34 & 52 \\
\hline 2030 & 14 & 43 & 83 \\
\hline 2035 & 14 & 51 & 134 \\
\hline 2040 & 14 & 58 & 216 \\
\hline 2045 & 14 & 64 & 348 \\
\hline 2050 & 14 & 69 & 561 \\
\hline
\end{tabular}

Source: Metcalf et al (2008).

Table 4 shows three different tax rates. Dingell poses a constant rate of $\$ 14$ per ton of $\mathrm{CO} 2$ equivalent, Stark studied the effects of a rate that increases over time but that is reduced in intensity in recent years, while Larson is clearly the most ambitious in that he establishes a rate which shows increasing increments. A graphical representation of the previous tax rates is as follows:

Figure 8. Graphical representation of the tax rates

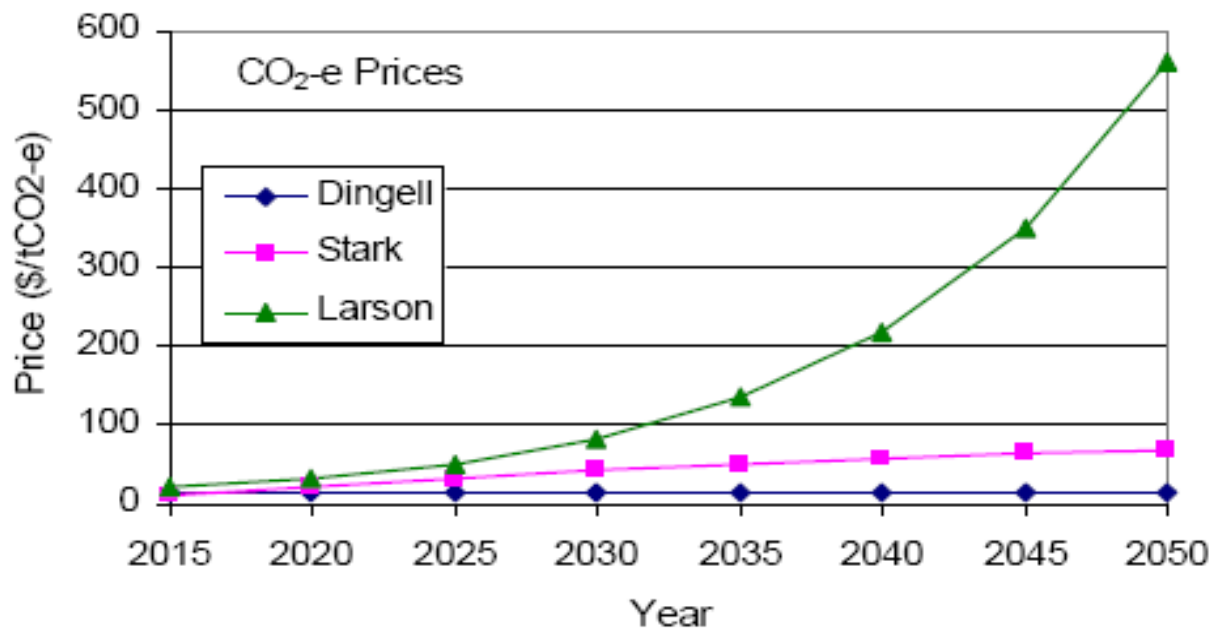

These estimates of carbon taxes result in different emission reduction trajectories: 
Figure 9. Emission trajectories.

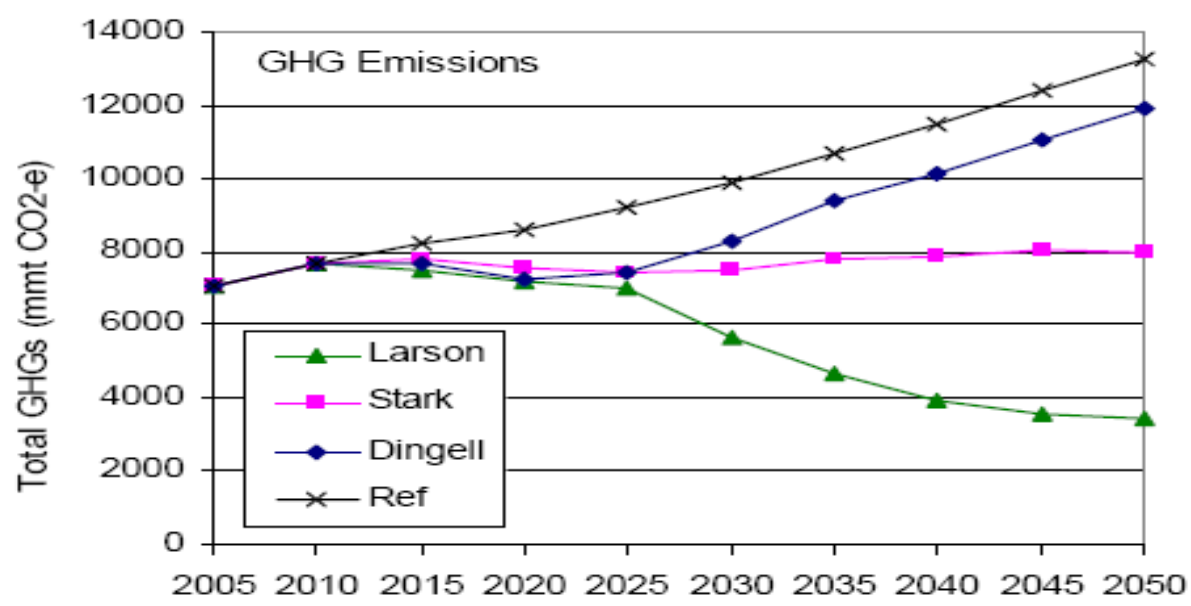

Source: Metcalf et al (2008).

Figure 9 shows how more ambitious rates (Larson) eventually lead to greater emission reductions. However, for the first 15 years, the application of different tax rates does not lead, in general, to important emission reductions or even great significant differences in these reductions.

These estimates of the tax rate result in changes in welfare (Table 5) which is measured for the loss of market consumption (that carries the tax) and offset by the gain in leisure time that also the tax produces (leisure associated to job losses):

Table 5. Welfare changes

\begin{tabular}{lccc}
\hline & \multicolumn{3}{c}{ Welfare Changes (\%) } \\
& Dingell & Stark & Larson \\
\hline $\mathbf{2 0 1 5}$ & 0.01 & 0.01 & 0.01 \\
$\mathbf{2 0 2 0}$ & -0.09 & -0.09 & -0.16 \\
$\mathbf{2 0 2 5}$ & -0.25 & -0.27 & -0.24 \\
$\mathbf{2 0 3 0}$ & -0.21 & -0.39 & -0.74 \\
$\mathbf{2 0 3 5}$ & 0.07 & -0.32 & -1.25 \\
$\mathbf{2 0 4 0}$ & 0.21 & -0.38 & -1.71 \\
$\mathbf{2 0 4 5}$ & 0.32 & -0.38 & -2.08 \\
$\mathbf{2 0 5 0}$ & 0.49 & -0.33 & -2.23 \\
\hline $\mathbf{2 0 1 2 - 2 0 1 5}$ & 0.10 & -0.30 & -1.21 \\
\hline
\end{tabular}




\section{Figure 10. Graphical representation of welfare changes}

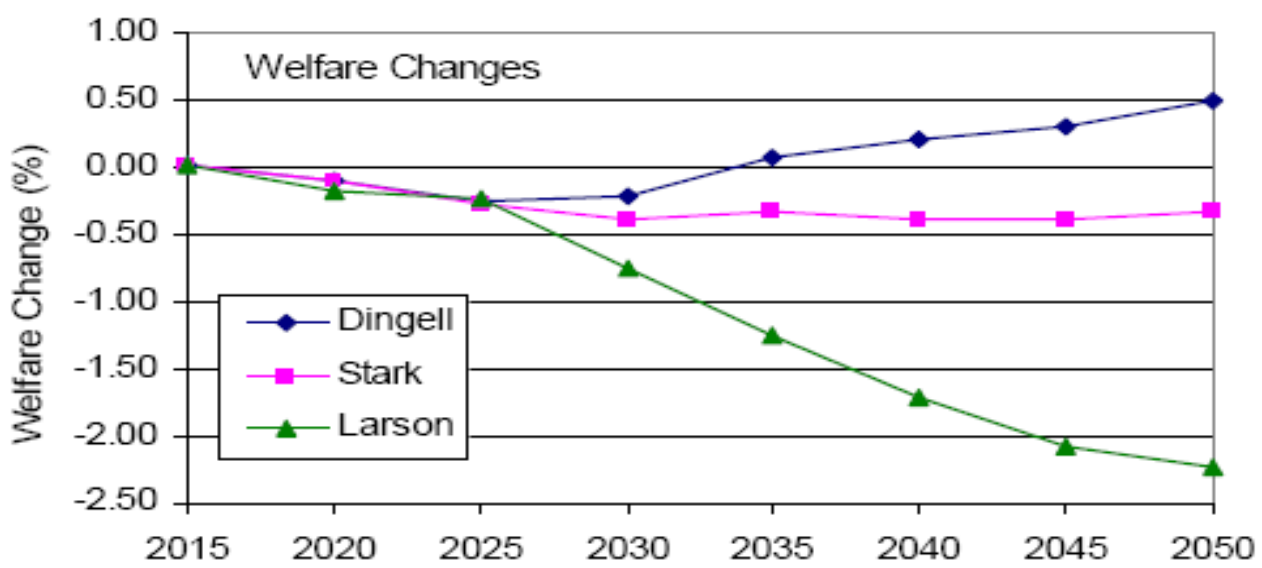

Source: These results can be found in Metcalf et al, (2008), where the authors give a rigorous interpretation of the EPPA model (Emissions Prediction and Policy Analysis). This model can be found in Paltsev et al (2005) version \# 4.

Table 5 and Figure 10 show the welfare losses that the different tax rates could generate. However, we must bear in mind that such losses could be cushioned using tax revenues to compensate the most affected population groups. In the same way, recycling the tax (reduction of other taxes on income from labor and capital) also offers a compensatory measure for the income losses.

\section{The elasticity issue}

One of the most important effects arising from the tax rate analysis is the elasticity issue. Associated with the tax rate there will be different percentage changes in fuel prices, which in turn, will lead to changes in consumption. The economic instrument relating the above variables is the "elasticity of demand with respect to the price," which is a measure of the sensitivity of consumption to changes in prices. To find out what price changes will be needed to produce a particular reduction of fossil fuel use we need to calculate the demand elasticity for these fuels, a task which is not easy for a number of reasons (Anderson, 1993).

First, the demand-price elasticity varies with the time period considered. If, say we have little time to react to a price increase, it is likely to maintain the same behavior, supporting therefore the price uptrend. You need to spend more time to change consumer behavior, for example, consumers decide to buy energysaving appliances.

Second, goods prices affect the demand not only for the goods but also for their substitutes. For example, an increase in the price of coal can relatively make cheaper oil or natural gas and, therefore, produce the shift from coal to these 
other fuels (Annex 1 shows an example of this particular case). The economic instrument that relates these variables is the "cross-elasticity of demand." The proposals for a carbon tax usually involve many price demand and crossed elasticities, for example, a coal price increase will affect the demand for oil and natural gas (increasing it) and his own (reducing demand); an oil price increase will affect the demand for coal and natural gas, etc..

Third, and of great importance, is the possibility of adopting more efficient technological changes. For example, a high carbon tax rate can be an incentive for a company to replace its production method for a less polluting one. But this new method could be not sufficiently developed when the tax is levied for the first time, so predicting what the effect of the tax will be depends on whether the technological development will take place at least in a not too long period, which would allow the company to replace their polluting technology for a more efficient one. Obviously, in the long run this problem disappears, since there is the possibility of combining advanced technology with tax.

A fourth issue is that the tax will affect the price before taxes, as producers will accept a reduction in their profit margins (with a possible reduction of the sale price) rather than accept a drop in sales. The tax percentage rate does not clearly lead to the same percentage increase in price. If profit margins decrease, then the increase in price due to the tax will be lower than the tax rate.

If we knew the demand response to an increase in fuel prices we could calculate emission reductions associated with a given carbon tax. All you would have to do to calculate changes in fuel consumption associated with each tax (coal, oil and natural gas), multiply these changes by the appropriate relative weight of emissions (emission rate for each fuel) and add the results of the three fuels. Few authors have made some attempts to estimate the elasticities of demand for energy, since they are not easy to estimate12. In addition, there is no guarantee that estimates based on historical data can predict future responses. In fact, the elasticities should be used to predict demand response to small changes in prices. If we only take into account these effects and ignore other important factors in the analysis, we could see what happens when price changes are large, since the aim is to have an idea of the energy demand response when we establish the tax under different assumptions.

Annex 1 shows the impact of $\$ 27$ per ton of $\mathrm{CO} 2$ equivalent tax on the prices and consumption of several fuels. There is a relative rise in coal price and a consequent reduction in consumption in favor of an increase in the consumption of petroleum and natural gas, due to greater cross-elasticity between the price of coal and the demand for these two fuels.

\footnotetext{
12 Barret (1991) presents for UK the hypothetical estimates of the demand and crossed elasticities for energy, as well as the necessary carbon tax to reduce emissions by $20 \%$. Demand elasticities fluctuate between -0.5 and -2 , while the cross elasticity fluctuate between 0.1 and 0.75 . For example, a coal demand elasticity of -0.5 means that a $1 \%$ increase in the price of coal will reduce fuel demand by $0.5 \%$. Similarly, cross-price elasticity between coal and oil of 0.1 means that a $1 \%$ increase in the price of coal will increase oil demand by 0.1 percent.
} 


\section{Equity and distribution}

The carbon tax is regressive. To assess the carbon tax distributional effects we must take into account an important issue, which is that people with low income tend to spend on energy a larger proportion of their total expenditure than the higher income groups, supporting, thus, a greater tax burden. This can be an argument against the carbon tax, but it weakens with the following reasons:

First, a carbon tax is regressive, but so are many alternatives available to reduce greenhouse gas emissions. For example, when setting energy efficiency standards for vehicles, appliances, etc, we are adopting regressive meassures, since the owners of these devices, which typically have higher incomes, pay, ultimately, lower energy bills. However, economic research shows that poor people prefer to buy less energy efficient items due to their reduced purchasing power, so the consumption of less efficient products will pay them with higher bills.

Second, the annual income of a family is a poor indicator of current welfare. Instead of evaluating the effects of the tax based on income and annual energy expenses for consumers, that indeed show the regresivity of the tax (the poor spend a larger fraction of their income on energy), we should choose the total consumption expenditure as the welfare indicator (Poterba, 1991). The reason is that a family income may vary from year to year, for both predictable and non-predictable facts, however, consumption is based on the long-term income. Studies conducted for the U.S. ${ }^{13}$ show that when household welfare is based on total consumption expenditure instead of annual income the regressivity of the tax lowers. This means that the total consumption expenditure is a more reliable indicator to measure the redistributive effects of the tax. This is mainly because families experience transitional changes in annual income - for example unemployment, sickness, etc. - But their expenses reflect long-term economic circumstances instead of transitional conditions.

Third, the tax revenue can be redistributed to lower-income groups. Indeed, the carbon tax has the same effect as an increase in energy prices in an economy that depends entirely on imported energy. In addition, the tax could generate substantial money income, money that could be put to good use within the country. It is obvious that all countries have taxes that generate revenue. The problem of these taxes is that they often give rise to significant distortions. For example, an income tax disincentives work, a tax on gains from the investment creates an incentive for consumers to substitute future consumption for present consumption, etc.. These distortions have a cost in terms of national product and, therefore, affect the economy growth14. A carbon tax corrects these distortions by making polluters pay the environmental costs of their actions. The establishment of a tax would not only help to protect the environment but also

\footnotetext{
${ }^{13}$ James Poterba shows his empirical results on the redistributive effects of the carbon tax referring, on the one hand, to the annual income, and the total consumption expenditure, on the other, in Global Warming, Economic Policy Responses, p.79.
}

${ }^{14}$ According to Reppeto Dower (1990), these distortions are a cost of between 4-7 percent of GDP in the U.S. 
would encourage the substitution of other income sources (income taxes, partnerships, etc.) that are damaging the economy ${ }^{15}$. This is what is known as "recycling the carbon tax."

Another alternative would be to invest some of the tax revenues in a low carbon economy. Here it would be necessary to resort to other revenue sources in order to replace the old technology with the new one based on carbon capture and storage. These existing but little used technologies will bring more energy efficiency and therefore lower emission levels. The disadvantage is that those resources require substantial investments.

Perhaps, the more supported option, but not the only one, is to maintain the neutrality of the tax (revenue and distributional effects neutral). This tax revenue would be used to reduce other taxes, maintaining then the progressivity (the carbon tax does not change the progressivity of the tax system $)^{16}$.

\section{A gradual tax}

An important issue about the carbon tax is whether is gradually applied over time and thus increases its rate, and even its base, or if, in another way, we impose a high rate from the first moment, without giving option to a transitional adaption period. Another approach is to exempt, in a first phase, emissions from the tax (up to a certain limit), for example, an emissions level equal to that of a reference year. The introduction of a high rate from the beginning has a double disadvantage: it carries administrative and emission reduction costs, an also the difficulty of being politically feasible. However, some studies support this approach (see Metcalf, et al, 2008). Supporters of the high rate say it maximizes the so-called "anticipation effect". If businesses understand and take into account that the tax will be introduced without any transitional period for them to adapt their investments to the new system, then they will start adapting and adjusting their decisions from the outset, anticipating future tax impacts on their business. However, a high rate tax would be politically unpopular. In fact, up to date, the European Union has failed to introduce a carbon tax due to lack of consensus.

Here we advocate for a gradual tax, as already stated at the outset. We argue that a tax with a progressive rate (little distorting) would benefit society since it would not increase costs geometrically, but will change over time as emission targets are being implemented. The studies shown earlier in this paper (Metcalf et al, 2008) show that in the medium term, it may be necessary to increase tax rates because, once we have achieved a significant emissions reduction in the early stages, emissions may start to grow again. Finally, once the emission cuts had been substantial we could then return to low tax rates and even eliminate

\footnotetext{
${ }^{15}$ Barker and Lewney (1990) compensate a decrease of VAT with the revenues from the carbon tax. In addition, the tax has no significant negative effects on growth. Since they set a quite high tax, hence it follows that the efficiency gains resulting from the reduction of VAT should also be large.

${ }^{16}$ Metcalf, G. E. (2007) provides an example based on this argument.
} 
the tax. This is important because tax rates must be adjusted to the new information on the marginal costs and benefits. We will have more and better information about climate change over time and, with these, new mitigation technologies will be applied. The big question is to how often should we change the tax rates.

In this regard, the question is clear and there will be little benefit derived to adjust interest rates in the short term as most of the opportunities to reduce emissions are related to long-term investments, such as industrial and energy sectors. In any case it would be desirable to have specific institutions that were responsible for setting the tax rates.

\section{Border taxation}

The border tax adjustments make sense when we move to a system where countries have different tax regimes. Many countries do not apply and may not apply ever carbon taxes. Being able to make adjustments when the goods are exported and imported is a solution for all countries to pay for the consumption of goods containing carbon. When the goods produced in a country that has no taxes on carbon are imported into a country that imposes these taxes, it arises a comparative advantage for untaxed products in relation to those being produced in countries with carbon taxation. This potential advantage lies in lower production costs on countries that have not taxed the carbon content. A border tax adjustment will consist of taxing imported products (in terms of their carbon content) from countries that do not tax the carbon content. The opposite case occurs when previously taxed products are exported to countries that tax carbon. In that case those countries should have a border compensation not to incur in double taxation.

Anyway, the most complicated issue for these adjustments is to determine the carbon content of imported goods. This problem is especially important in the case of non-Annex I countries of the Framework Convention on Climate Change (China and other developing countries with markedly exporter power). These countries do not regularly produce detailed carbon emission inventories, which greatly complicates the determination of the carbon content of its exported products. Possibly they would neither accept putting a price on carbon.

It is hoped also that the economic crisis leads to a greater international coordination on climate change. It seems clear that in a context of widespread loss of jobs and economic activity, the phenomena of fugitive emissions to countries lacking of climate change policies would be subject of special attention, being even able to influence in the definition of future policies (border balancing tariffs, exempted sectors, etc..). It is also likely that there are significant incentives for the participation of developing countries in climate change mechanisms (particularly China and India), crucial to the success of any strategy in this field worldwide. It is possible that explicit technological aids play a key role in this regard, helping to justify the foreseeable technological effort of 
the developed world and to limit the effects of the economic crisis on the countries with the least economic capacity (Labandeira, 2011).

\section{Conclusions}

An important objective of any palliative policy leading to mitigate the adverse effects of global warming must be to implement the maximum emission reductions for a given level of expenditure. This is a cost-efficient policy. Knowing if preventive action is needed depends on the relationship between the costs of avoiding greenhouse gas emissions and the damage these gases can cause.

Without a radical change in the energy model, the forecast for the following decades points to a world energy consumption of $60 \%$ higher than today, with oil and coal being the higher consumed sources, natural gas having the higher growth rate, and a slight increase for nuclear and renewable energies. This situation urges a change in the production model together with mitigation measures capable of achieving a gradual reduction of carbon emissions.

In order not to lose the efficiency target, a tax on emissions provides strong incentives to develop and implement new and cleaner technologies, achieving higher levels of efficiency than any other policies based on the quantitative control of emissions. In the same way, a correctly managed tax being adopted by a large majority of countries, would be able to implement better levels of efficiency and effectiveness than the current emission permit systems. The tax is able to get a net cut on carbon emissions, as companies, in order to reduce the tax size, will have an incentive to reduce them.

Finally, it should be borne in mind that climate change constitutes one of the greatest markets failures, at least a great failure attributable to the market which inevitably interacts with other market imperfections. Any effective global response will at least require three elements of economic policy: the carbon price applied through taxation, emissions trading or regulation, a policy of supporting innovation and application of low carbon technologies, and finally, action to remove any barriers to energy efficiency and, also inform, educate and persuade individuals about what they can do to respond to climate change. Clearly, climate change demands an international response, founded on a shared understanding of long-term goals and an agreement on frameworks for action.

\section{REFERENCES}

Barret, S. "Global Warming: Economics of a Carbon Tax", en Pearce, D. et al., (1991). Blueprint 2 ( $2^{\text {nd }}$ part of Blueprint for a Green Economy, 1989). Eartscan Publications Limited, London, (pp. 31-51).

Bruvoll, A., and B. M. Larsen (2004): "Greenhouse Gas Emissions in Norway: Do Carbon Taxes Work?,".Energy Policy, 32, 493-505, 2004. 
Carlson, c., and G. E. Metcalf: "Energy Tax Incentives and the Alternative Minimum Tax," National Tax Journal, 61, 477-491, 2008.

Clark, L. E., J. A. Edmonds, H. D. Jacoby, H. M. Pitcher, j. Reilly, and R.G. Richels. "Scenarios of Greenhouse Gas Emissions and Atmopheric Concentrations, Synthesis and Assessment Product 2.1a, 2007.

Cline, W.R. The Economics of Global Warming. Institute for International Economics. Washinton DC, 1992.

Clarke, R., Boero, G., y Winters, L.A. "Controlling Greenhouse Gases: A Survey of Global Macroeconomic Studies". Bull. Econ. Res., October, 48 (4), pp. 269308, 1996.

Convery, F. J., and L. Redmond. "Market and Price Developments in the European Union Emissions Trading Scheme". Review of Environmental Economics and Policy, 1, 88-111, 2007.

European Commission. "A Resource-efficient Europe. Flagship Initiative under the Europe 2020 Strategy". European Commission Communicate, COM(2011) 21.

- (2011a): "A Roadmap for moving to a competitive low -carbon economy in 20150". COM(2011) 112/4.

Fullerton, D., and G. E. Metcalf. "Environmental Taxed and the DoubleDividend Hypothesis: Did You Really Expect Something for Nothing?," ChicagoKent Law Review, 73, 221-256, 1998.

Gago, A; Labandeira, X. "Cambio climático. Impuestos y Reformas Fiscales". Estudios de Economía Política, 19 (2011):147-161.

García, Cristina. "El cambio Climático: Impuestos sobre el Carbono, Coste y Eficiencia Económica". Publisher digital by Universidad Pontificia de Comillas, Congreso Internacional "Desafíos del Cambio Climátco" (25-26 febrero de 2013).

- "El Cambio Climático: los aspectos científicos y económicos más relevantes". Nómadas. Revista Crítica de Ciencias Sociales y Jurídicas | 32 (2011.4)

- "La Evidencia del Cambio Climático. La necesidad de las Políticas Preventivas". Nómadas (25). Revista Crítica de Ciencias Sociales y Jurídicas, 2010.

- "Los costes de la política de cambio climático: una aproximación teórica". Revista Crítica de Ciencias sociales y jurídicas, 2010.

- "La Economía del Cambio climático: las políticas preventivas y sus costes". Revista CIP-ECOSOCIAL. Boletín ECOS nº 9, 2009. 
- "Comparación entre Impuestos sobre el Carbono y Permisos de emisiones en el Marco de la Eficiencia económica: una evaluación teórica". Anales de Economía Aplicada, nº XXII, 2008.

- "El Análisis coste-beneficio y la dificultad de su aplicación al cambio climático". Revista Estudios de Economía Aplicada, 2006.

- "El cambio climático: análisis de las causas" y "El cambio climático análisis de los impactos". UEM. Ediciones, 2001.

- "El Cambio Climático: Estado de la Cuestión y Aspectos Científicos". DT 8/99. UEM-CEES Ediciones. Nómadas. Revista Crítica de Ciencias Sociales y Jurídicas | 32 (2011.4)

GRUBB, M. "Copenhagen, back to the future?. In Climate Policy, Vol. 10, núm 2., 2010.

International Energy Outlook . U.S. Energy Information Administration, 2011.

IPCC. "Summary for Policymakers", en IPCC, Climate Change 2007: The Physical Science Basis: Contribution of Working Group I to the Fourth Assessment Report of the Intergovernmental Panel on Climate Change (Cambridge: Cambridge University Press, 2007a).

IPCC. "Summary for Policymakers", en IPCC, Climate Change 2007: Impacts, Adaptation and Vulnerability. Contribution of Working Group II to the Fourth Assessment Report of the Intergovernmental Panel on Climate Change, (Cambridge: Cambridge University Press, 2007b).

Jorgenson, D.W, y Wilcoxen, P.J. "The Cost of Controlling US Carbon Dioxide Emissions". Harvard University, Cambridge, MA., 1990.

Kesicki, F. "Marginal Abatement Cost Curves for Policy Making-Expert-Based vs Model-Derived Curves". Energy Institute, University College London, 2010.

Labandeira, X . "Cambio Climático y Crisis Económica". FEDEA, (Universidad de Vigo), 2011.

Metcalf, G. E., S. Palstev, J. Reilly, H. D. Jacoby, and J. Holak : "Analysis of U.S. Greenhouse Gas Tax Proposals," Cambridge: MIT, 2008.

Metcalf, G. E., S. Palstev, J. Reilly, H. D. Jacoby, A. GURGEL, A. Sokolov, and J. Holak. "Analysis of a Carbon Tax to Reduce U.S. Greenhouse Gas Emissions," Cambridge, MA: MIT Joint Program on the Science and Policy of Global Change, 2008.

Metcalf, G. E., and J. M. Reilly. "Policy Options for Controlling Greenhouse Gas Emissions: Implications for Agriculture,"Choices, 23, 34-37, 2008. 
Metcalf, G.E and Weisbach D. "The Design of a Carbon Tax". The Law school of University of Chicago. Working paper n² 254, 2009.

Nordhaus, W. "After Kyoto: Alternative Mechanisms to Control Global Warming".Yale University, 2002.

Nordhaus, W. D. "To Tax or Not to Tax: Alternative Approaches to Slowing Global Warming,"Review of Environmental Economics and Policy,1,26-44, 2007.

Paltsev, S; Reilly, J.M; Jacoby, H.D. " The MIT Emissions Prediction and Policy Analysis (EPPA) Model: version 4. Massachusetts Institute of Technology, 2005.

Pigou, A. C. The Economics of Welfare. London: Weidenfeld and Nicolson, 1938.

Poterba, J."Tax policy to Combat Global Warming: On Designing a Carbon Tax". En Global Warming: Economic Policy Approaches. Edited by Dornbush, R.D. and Poterba, J.M, pp. 72-98. Cambridge, MA:MIT Press, 1991.

Reilly, J., H. D. Jacoby, and R. G. Prinn . "Multi-Gas Contributors to Global Climate Change, Climate Impacts and Mitigation Costs," Pew Center on Global Climate Change, 2003.

Stern, N. Stern Review on the Economics of Climate Change, www.sternreview.org.uk , 2006.

Stern, N. The Economics of Climate Change, the Stern Review. Cambridge, UK: Cambridge University Press, 2007.

UNFCCC Press release.UN Climate Change Conference in Cancun delivers balanced package of decisions, restores faith in multilateral process. Cancun, México, 11 diciembre de 2010. UNFCCC documentos oficiales: www.unfccc.int, 2010.

Whalley, J. y Wigle, R. "Cutting CO2 Emissions: The Effects of Alternative Policy Approaches"en International Trade and Environment, Judith Dean (ed). Ashgate Publishers, 2002.

William D. Collins, Cecilia M. Bitz, Maurice I. Blackmon. " The Community Climate System Model Version 3 (CCSM3)". Journal of Climate, vol, 19, 2005.

World Resources Institute. Survey. The Right Climate for Carbon Taxes: Creating Economic Incentives to Protect the Atmosphere, 1995.

World Resources Institute. "Climate Analysis Indicators Tool, Online Database Version 3.0". World Resources Institute, 2006. 


\section{ANNEX I}

Changes in fuel prices associated with a tax of \$ 27 per ton of carbon:

\begin{tabular}{rccc}
\hline Fuel & $\begin{array}{c}\text { Base Price } \\
\text { Ave. 2002- } \\
\mathbf{2 0 0 6} \\
\mathbf{( 2 0 0 5 \$ )}\end{array}$ & $\begin{array}{c}\text { Added } \\
\text { Cost }(\$)\end{array}$ & $\begin{array}{c}\text { Added Cost } \\
(\%)\end{array}$ \\
\hline Crude Oil (\$/bbl) & $\$ 40.00$ & $\$ 12.20$ & $30 \%$ \\
Regular Gasoline (\$/gal) & $\$ 1.82$ & $\$ 0.26$ & $14 \%$ \\
Heating Oil (\$/gal) & $\$ 1.35$ & $\$ 0.29$ & $21 \%$ \\
Wellhead Natural Gas (\$/tcf) & $\$ 5.40$ & $\$ 1.49$ & $28 \%$ \\
Residential Natural Gas (\$/tcf) & $\$ 11.05$ & $\$ 1.50$ & $14 \%$ \\
Utility Coal (\$/short ton) & $\$ 26.70$ & $\$ 55.30$ & $207 \%$ \\
& & & \\
\hline
\end{tabular}

Incidence previous tax on consumption of fossil fuels:

\begin{tabular}{lcccccccc}
\hline & $\mathbf{2 0 1 5}$ & $\mathbf{2 0 2 0}$ & $\mathbf{2 0 2 5}$ & $\mathbf{2 0 3 0}$ & $\mathbf{2 0 3 5}$ & $\mathbf{2 0 4 0}$ & $\mathbf{2 0 4 5}$ & $\mathbf{2 0 5 0}$ \\
\hline Coal & & & & & & & & \\
$\quad$ Dingell & 0.97 & 0.95 & 0.91 & 0.93 & 0.93 & 0.93 & 0.94 & 0.94 \\
Stark & 0.97 & 0.97 & 0.95 & 0.95 & 0.96 & 0.97 & 0.98 & 0.98 \\
Larson & 0.98 & 0.97 & 0.97 & 0.97 & 0.98 & 0.99 & 1.00 & 1.00 \\
287 bmt & 0.98 & 0.97 & 0.94 & 0.94 & 0.95 & 0.96 & 0.97 & 0.98 \\
Natural Gas & & & & & & & & \\
Dingell & 0.78 & 1.25 & 2.88 & 2.23 & 2.30 & 2.27 & 2.19 & 1.59 \\
Stark & 0.79 & 1.01 & 1.75 & 2.03 & 2.01 & 1.28 & 0.86 & 0.14 \\
Larson & 0.78 & 0.98 & 1.43 & 1.33 & 0.94 & 0.73 & 0.60 & 0.68 \\
287 bmt & 0.73 & 0.98 & 2.14 & 2.52 & 1.85 & 1.49 & 0.73 & 0.14 \\
Crude 0il & & & & & & & & \\
Dingell & 0.78 & 0.67 & 0.07 & 0.02 & 0.55 & 0.60 & 0.70 & 0.71 \\
Stark & 0.74 & 0.76 & 0.53 & 0.58 & 0.74 & 0.74 & 0.75 & 0.71 \\
Larson & 0.81 & 0.81 & 0.66 & 0.61 & 0.72 & 0.78 & 0.84 & 0.88 \\
287 bmt & 0.89 & 0.87 & 0.85 & 0.84 & 0.80 & 0.78 & 0.77 & 0.73 \\
\hline
\end{tabular}

Source: Metcalf, G et al, 2008. Analysis of a Carbon Tax to Reduce U.S. Greenhouse Gas Emissions, "Cambridge, MA: MIT Joint Program on the Science and Policy of Global Change. 


\section{ANNEX 2}

\section{CARBON TAXES IN THE WORLD}

\begin{tabular}{|c|c|c|}
\hline Country/Province/Mun. & Tax Name & Enactment \\
\hline Sweden & $\begin{array}{l}\mathrm{CO}_{2} \text { levy on heating and } \\
\text { process fuels }\end{array}$ & 2008 \\
\hline Finland & $\begin{array}{l}\text { Charge on exceeding of GHG } \\
\text { emission limits }\end{array}$ & 2004 \\
\hline \multirow[t]{3}{*}{ Norway } & $\mathrm{CO}_{2}$-tax on mineral products & 1991 \\
\hline & $\begin{array}{l}\text { Environmental tax on } \\
\text { greenhouse gases - HFC and } \\
\text { PFC }\end{array}$ & 2003 \\
\hline & $\begin{array}{l}\text { Tax on } \mathrm{CO}_{2} \text { emissions in } \\
\text { petroleum activities on the } \\
\text { continental shelf }\end{array}$ & 1991 \\
\hline Denmark & Duty on $\mathrm{CO}_{2}$ & 1998 \\
\hline Quebec, Canada & Hydrocarbon Duty & 2008 \\
\hline British Columbia, Canada & Carbon Tax & 2008 \\
\hline $\begin{array}{l}\text { City of Boulder, Colorado, } \\
\text { USA }\end{array}$ & Carbon Tax & $2006^{32}$ \\
\hline $\begin{array}{l}\text { San Francisco Bay Area, } \\
\text { California, USA }\end{array}$ & Carbon Tax on Businesses & $2008^{33}$ \\
\hline $\begin{array}{l}\text { Montgomery County, } \\
\text { Maryland, USA }\end{array}$ & $\begin{array}{l}\text { Carbon Tax on Stationary } \\
\text { Sources }\end{array}$ & $2010^{34}$ \\
\hline
\end{tabular}

OECD/EEA Database on Instruments used for Environmental Policy and Natural Resources Management, available at http://www2.oecd.org/ecoinst/queries/index.htm. 


\section{ANNEX 3}

Tax rates and costs under imperfect information.

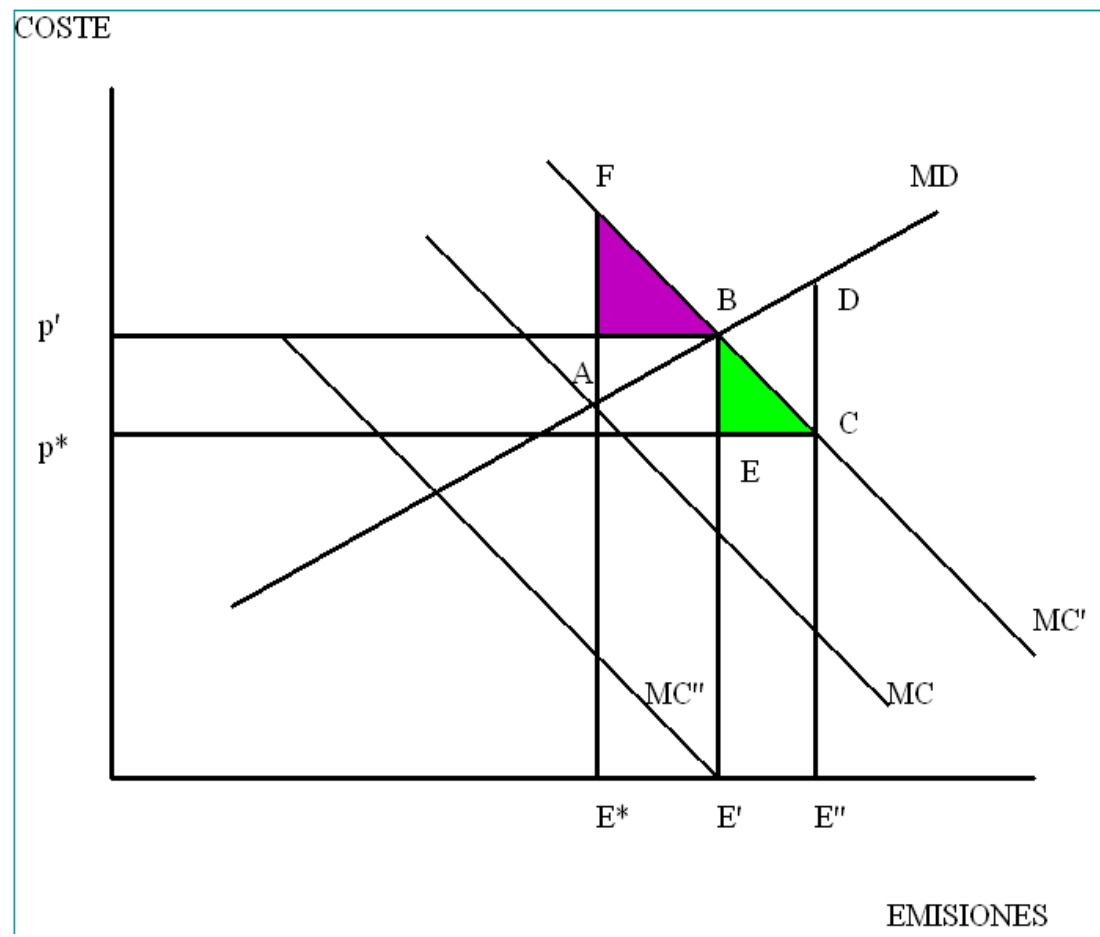

Source: Authors. The graph shows the cost structure of the factory: the estimated marginal cost curve but uncertain (MC) and the marginal cost curves known relatively, $\mathrm{MC}^{\prime}$, or $\mathrm{MC}^{\prime}$. The estimated curve is the average of the above. Furthermore, assume the planner knows the marginal damage curve (MD) without uncertainty. Based on this information the planner will find that the optimal level of emissions is $E^{*}$, since at that level the marginal cost of reducing emissions is equal to the marginal cost of the damage. Then the total expected emission reductions and the damage cost are minimum at this level. $\mathrm{P}^{\prime}$ and $\mathrm{P}^{*}$ are the different tax rates. The shaded areas represent the net costs of the instruments used, taxes (ECB) or permits (ABF) that depend on the elasticities of the curves MC and MD. More detailed information can be found in Garcia, C (2012 and 2013). 